\title{
COMMUNICATIVE LANGUAGE TEACHING TECHNIQUES AND LEARNING STYLES ON THE STUDENT'S SPEAKING SKILL AT PRIVATE VOCATIONAL SCHOOL
}

\author{
Irfan Hadi \\ Program of English Education, Faculty of Language and Art, University of Indraprasta PGRI \\ Jalan Nangka No. 58C Tanjung Barat, Jagakarsa, Jakarta Selatan 12530 \\ pakirfan@rocketmail.com
}

\begin{abstract}
The purpose of the research is to analyze the effect of teaching techniques of Role Play, Information Gap and Learning Style which relate to the dominance of right brain and left brain toward student's speaking skill at Private Vocational School in South Jakarta. The data is collected by using two techniques in teaching English speaking skill and learning style. The improvement of teaching quality and learning process is held by using appropriate material with the curriculum and the syllabus. The method used in this research is experiment method. The data is taken by conducting exercise and distributing questionnaire. Findings show that the Sig. Score of teaching technique is 0,000 which is lower than $0.05(0.000<0.05)$ means that the hypothesis works and Ho is rejected as there is an influence between teaching technique towards speaking skill. The sig. Score of learning style is 0.968 is higher than $0.05(0.968>0.05)$ means that Ho is accepted as there is no influence between learning style towards speaking skill. The sig. Score of interaction is 0.562 is higher than $0.05(0.562>0.05)$ means that Ho is accepted as there is no influence interaction between teaching technique and learning style towards speaking skill.
\end{abstract}

Key words: role play, information gap, right brain dominant, left brain dominant, speaking skill

\begin{abstract}
ABSTRAK
Tujuan dari penelitian ini adalah untuk mengetahui pengaruh teknik pengajaran role play, information gap, dan gaya belajar yang berkenaan dengan dominan otak kanan dan otak kiri terhadap kemampuan berbicara bahasa Inggris siswa Sekolah Menengah Kejuruan di Jakarta Selatan. Data dikumpulkan dengan menggunakan dua teknik dalam pengajaran kemampuan berbicara bahasa Inggris dan gaya belajar. Pengembangan kualitas pengajaran dan proses belajar dilakukan melalui pemberian materi yang sesuai dengan kurikulum dan silabus. Metode yang digunakan dalam penelitian ini adalah metode eksperimen. Data diperoleh dengan pemberian latihan dan kuesioner. Hasil penelitian menunjukkan bahwa nilai sigma teknik pengajaran adalah 0,000 lebih rendah dari 0.05 (0.000<0.05), hal ini berarti bahwa hipotesis sesuai dan Ho ditolak, sehingga terdapat sebuah pengaruh antara teknik pengajaran terhadap kemampuan berbicara. Selanjutnya, nilai sigma gaya belajar yang berkenaan dengan dominan otak kanan dan dominan otak kiri adalah 0.968 lebih tinggi dari $0.05(0.968>0.05)$ hal ini berarti bahwa Ho diterima, sehingga tidak ada pengaruh antara gaya belajar terhadap kemampuan berbicara. Nilai sigma interaksi adalah 0.562 lebih tinggi dari $0.05(0.562>0.05)$ yang berarti bahwa Ho diterima sehingga tidak ada pengaruh interaksi antara teknik pengajaran dan gaya belajar terhadap kemampuan berbicara.
\end{abstract}

Kata kunci: role play, information gap, dominan otak kanan, dominan otak kiri, kemampuan berbicara 


\section{INTRODUCTION}

The world of language teaching has developed significantly for years. This development, certainly, brings lots of changes. The most particular changes lay on the perspective about the students. The teacher-centered model in which the teacher plays the most important roles in the class and is the central of activity has been changed into student-centered, because it does not give meaningful advantages.

The most popular student-centered teaching is Communicative Language Teaching (CLT). Communicative Language Teaching emphasizes on communiaction and real life situations. Using Communicative Language Teaching, the teacher is supposed to create the communicative circumtances in which real life communication can be applied. There are some techniques related to Communicative Language Teaching asserted by Richards in Jolliffe (2007) who distinguished two main types of techniques in Communicative Language Teaching; functional communication and social interaction. Functional communication includes tasks based activities, following directions, and solving problems from shared clues. Meanwhile, social interaction includes some activities such as dialogue, role play, simulation, brainstorming, discussion, debate, storytelling and information gap.

In the speaking class, there are some teaching techniques that can be applied by teachers. Role play and information gap are two techniques that can facilitate the communicative language learning. By conducting role play and information gap activities, students can get involved in the language use communicatively. One of the factors which comes from the students is their learning styles. An important factor in understanding learning style is held by understanding brain fuctioning. The students' learning styles can be influenced by the participation of the brain hemispheres. Both sides of the brain can function but in different strategies, and one side may be dominant. Students who are left brain dominant will have different learning styles comparing with the students who are right brain dominant. Intellectual, logical, and analytic functions appear to be largely located in the left hemisphere, while the right hemisphere controls function related to emotional and social needs.

In order to enable the most students to learn as much as they can, whether they are left brain dominant or right brain dominant, teachers need to give them every advantage, including teaching programs that enable them to start out in a relatively comfortable and stress-free way. That means that the teachers should give the students the opportunity to learn in their own styles. Today's world requires the aim of teaching English should enable the students to communicate in that language. Speaking skill is one of the main priorities of most english teaching.

Speaking is aimed at enabling the students to use the language properly. In order to reach that aim, the teachers, certainly need to provide the appropriate techniques to promote the communication activities. With regards to the fact above, it is necessary to do a kind of research to find out the most appropriate teaching techniques according to the students' learning styles so that the learning and teaching process can be conducted more effectively.

This present research is an experimental research in which two techniques are compared-role play and information gap. On the one hand, role play is a teaching technique which demands the creative and active 
involvement of the students. Information gap, on the other hand, is a teaching technique that demands the students to rely upon prepared information. Although these two techniques are quite different, both are considerd as the communicative language teaching techniques. In addition, to compare these two techniques, this research also involves other factors, namely learning styles, which are categorized into leftbrain dominance and right-brain dominance. These factors are chosen to prove that both hemispheres (brain-side) have their own contribution to language development.

Speaking is one of communication skills in which the speaker shares information while at the same time he/she also gets information from the listener. For most people, the ability to speak a language has often been viewed as the most demanding of the other three skills. Jefferson (2007:41) stated that "Speaking is the process of building and sharing meaning through the use of verbal and non-verbal symbols, in a variety of context." By speaking, someone can communicate his ideas or information, and shares them to others at any situations and in a various contexts.

Philips (2007:26) stated that "Speaking is an interactive process constructing meaning that involves producing and receiving and processing". Speaking is the productive aural/oral skill which consists of producing systematic verbal utterances to convey meaning. Moreover, Jordan (2009) explained that speaking is the process of expressing thought, idea or feeling in the form of spoken language. Based on the definitions above, speaking is the process of conveying meaning, expressing idea and feeling through verbal utterances at any situations and in various contexts. We can conclude that speaking skill is one's ability to perform and share meaning through the knowledge of a language system in the form of oral activity that has been acquired by practice or training.

Richards in Jolliffe (2007:57) stated that "Communicative Language Teaching is an approach which refers to a diverse set of principles that reflect a communicative view of language learning and that can be used to suport a wide variety of clasroom procedures". There are some learning and teaching techniques that can be used in Communicative Language Teaching class, for example, role play, information gap, language exchanges, simulation, discussion, game, pair work and group work. All these techniques can engage the learners in communication process.

Techniques consist of activities which can be used by the teacher in the teaching process that were derived from teaching method and approach. In other words, when a teacher wants to apply a certain technique, she/he has to match the technique with the method and approach she/he is going to use in the teaching process. Role play is very important in Communicative Language Teaching (CLT) because it gives students the opportunity to practice communicating in different social context and in different social roles.

The definition of a role play according to Bailey is a speaking activity in which the students take the part of other people and interact using the characteristics of those people. This definition is supported by Kodotchigova who determined role play as a teaching technique in which the students are asked to identify with the given roles to interact with the other role characters within the given socio-cultural situation. Role play is one of a whole gamut of communicative techniques which develops fluency in language students which promote interaction in the 
classroom, and which increases motivation.

Further, there are some reasons to use role play in language class. Here is a list of the main reasons: through role play activities, a very wide variety of experience can be brought into the classroom. By using role play, the teacher can train the students in speaking skills in any situation; role play puts students in the situation in which they are required to use and develop the language; students can try out and experiment with the language in a friendly and safe environment of a classroom; role play can help many shy students by providing them with a mask. The students are deliberated by role play as they no longer feel that their own personality is implicated.

Referring to what has been explained above, it can be concluded that a role play is a classroom technique that encourages students to participate actively in the process of learning in which learners play a part, and experience the language in context of real life communication. Information gap technique refers to the activity in which learners must use the target language to convey information known to them but not to their speaking partners. In this activity, students are supposed to be working in pairs. One student will have the information that the other partners will share their information. Each partner plays an important role because the task cannot be completed if the partners do not provide the information the others need.

Information gap technique is a communicative language teaching technique which brings the language to life for students and usually involves pair work activities. Every person has his/her own preferred way of learning that is determined by their cultural and educational background, and their personalities. Those two terms of learning style have been used to describe an individual's natural, habitual, and preferred way of absorbing, processing, and retaining new information and skills. Zwiers (2010:17) stated that "Learning styles are relatively stable (though are not unchangeable)". A more detailed description was presented by Brown in Patel and Jain (2008:38) who stated that "Learning styles might be thought of as cognitive, affective, and physiological traits that are relatively stable indicators of how students perceive, interact, and respond to the learning environment". From the above definitions, it can be concluded that learning style is the different ways for people to learn and how they perceive, interact, and respond to the learning environment. Christison in Patel and Jain (2008) categorized learning styles into three types. The first type is cognitive styles. Cognitive styles are sub-grouped into six areas: field dependent, field independent, analytic, global, reflective and impulsive. The second type is sensory styles which are divided into two categories; perceptual and environmental learning styles. Perceptual consists of visual, auditory, tactile or kinesthetic. Environmental consists of physical and sosiological. The third type is personality styles. The personality styles are sub-grouped into two; tolerance of ambiguity and left and right brain dominance. Brain dominance refers to a preference for using one hemisphere of the brain over the other hemisphere. The left hemisphere of the brain rational, analytical, and verbal, while the right hemisphere is holistic and intuitive, responsive to visual imagery.

\section{METHOD}

In accordance with the problem statement and the objective of this study, 
the researcher conducted an experimental research. Doing this

research, the researcher treated two different experimental classes: class A1 with for role play technique and A2 with information gap technique. Likewise, the students in both classes were asked to answer the learning styles questionnaire which was adapted from the Hermann Brain Dominance Instrument at the end of the treatment as to find out the effect of it on the speaking skill. The research is designed by a factorial design $2 \times 2$ as follows:

Table 1. Factorial Design $2 \times 2$

\begin{tabular}{|l|c|c|}
\hline LS* & $\begin{array}{c}\text { Role Play } \\
\text { Technique } \\
\left(\mathrm{A}_{1}\right)\end{array}$ & $\begin{array}{c}\text { Information } \\
\text { Gap Technique } \\
\left(\mathrm{A}_{2}\right)\end{array}$ \\
\hline $\begin{array}{l}\text { Right-brain } \\
\text { dominant }\left(\mathrm{B}_{1}\right)\end{array}$ & $\mathrm{A}_{1} \mathrm{~B}_{1}$ & $\mathrm{~A}_{2} \mathrm{~B}_{1}$ \\
\hline $\begin{array}{l}\text { Left-brain } \\
\text { dominant }\left(\mathrm{B}_{2}\right)\end{array}$ & $\mathrm{A}_{1} \mathrm{~B}_{2}$ & $\mathrm{~A}_{2} \mathrm{~B}_{2}$ \\
\hline Total & $\mathrm{A}$ & $\mathrm{B}$ \\
\hline
\end{tabular}

$\mathrm{TT}^{*}=$ Teaching Techniques

$\mathrm{LS}^{*}=$ Learning Styles

The population of this research was all atudents at SMK Kharismawita 1 Jakarta who learned english subject. The sample of this research was taken based on the multiple staged method with equal characteristic and probability. There were two classes treated in this experiment, one was class XI AK 1 which was treated by using Role Play technique and another was class XI AK2 which was treated by using Information Gap technique. The number of students in each class was 24 . The sample was selected from those who took final test and answered all the learning style inventory questionnaire.

The composition of the sample according to the treatment can be seen in the following table:
Table 2. TheComposition of the Sample

\begin{tabular}{|l|c|c|c|}
\hline LS* & $\begin{array}{l}\text { Role Play } \\
\text { Technique } \\
\left(\mathrm{A}_{1}\right)\end{array}$ & $\begin{array}{l}\text { Information } \\
\text { Gap } \\
\text { Technique } \\
\left(\mathrm{A}_{2}\right)\end{array}$ & Total \\
\hline $\begin{array}{l}\text { Right- } \\
\text { brain } \\
\text { dominant } \\
\left(\mathrm{B}_{1}\right)\end{array}$ & 14 & 13 & 27 \\
\hline $\begin{array}{l}\text { Left-brain } \\
\text { dominant } \\
\left(\mathrm{B}_{2}\right)\end{array}$ & 10 & 11 & 21 \\
\hline Total & 24 & 24 & 48 \\
\hline
\end{tabular}

In testing the null hypotesis, twoway Analysis of Variance (ANOVA 2X2) technique was adopted after doing a required test which included normality and homogeneity. The null hypotheses of this study which were tested as follows: $\mathrm{H}_{01} \quad$ : The speaking skill of the students resulting from Role Play technique is the same or lower than that resulting from information gap technique. The speaking skill of the students resulting form Role play technique is the same or lower than that resulting from information gap technique.

$\mathrm{H}_{02}$ : The right-brain dominant students' speaking skill resulting from Role play technique is the same or lower than that resulting from information gap technique

$\mathrm{H}_{03}$ : The left-brain dominant students' speaking skill resulting from information gap technique is the same or lower than that resulting from role playing technique

$\mathrm{H}_{04}$ : There is no influence of interaction between communicative language teaching techniques and learning styles on the students speaking skill. 


\section{RESULTS AND DISCUSSION}

Data description in this research comprises six parts: 1) the data of students' speaking skill resulting from role play technique, 2) the data of right brain dominant students' speaking skill resulting from role play technique, 3 ) the data of left brain dominant students speaking skill resulting from role play technique, 4) the data of students' speaking skill resulting from information gap technique, 5) the data of right brain dominant students' speaking skill resulting from information gap technique, 6) the data of left brain dominant students speaking skill resulting from information gap technique.

In general, the data descriptions provide the description of the characteristic of the students' speaking skill after being treated with role play technique and information gap technique both for the right brain dominant students and the left brain dominant students.

\section{Data of Students' Speaking Skill Resulting from Role Play Technique} (A1)

The whole scores of speaking skill of the students who studied with role play technique ranged between 68 as the lowest, and 84 as the highest score. By using role play technique students in this group received average score of 74.67 , median score of 75 with deviation standard of 4.79 . The multiple modus scores; 68,00 occur in the speaking score frequency distribution of the left brain dominant students who study with role play technique.
Table 3. Data of Students' Speaking Skill Resulting from Role Play

Technique $\left(\mathrm{A}_{1}\right)$

Statistics

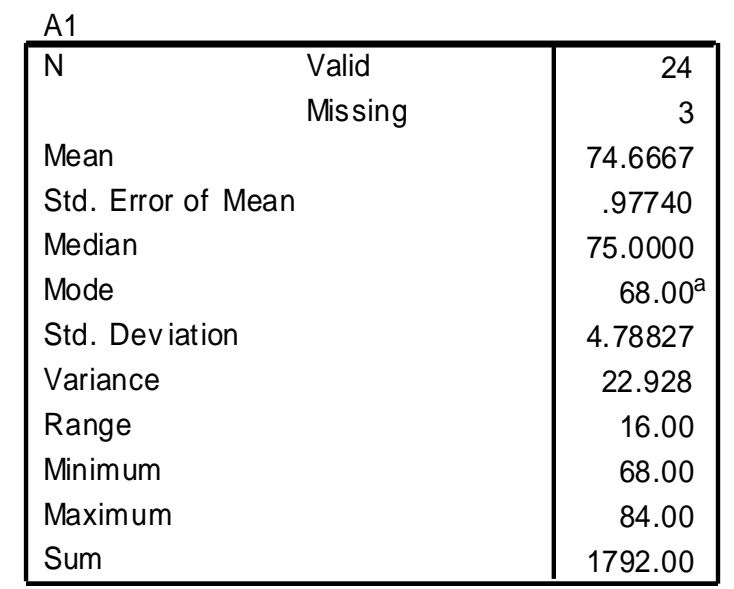

a. Multiple modes exist. The smallest value is shown

The position of the median score is closed to the average score (mean). Since the median score is higher than the average score, it can be said that the number of students who receive the score above the average is higher than the students who receive the score below the average. However, the average speaking skill of students who study with role play can be categorized as high.

As the mean score is 74.67 , from table 3 , it can be seen that 11 students or $45.8 \%$ of the whole class have scores under the medium range, 14 students or $55.2 \%$ get the score above the average ones. Based on the explanation above it can be concluded that the score of students' speaking test resulting from role play technique can be categorized as high.

\section{Data of Right Brain Dominant Students'}

Speaking Skill Resulting from Role Play Technique $\left(A_{1} B_{1}\right)$

The speaking skill of the right brain dominant students resulting from role play teaching technique, ranges between 68 and 84, in which 68 is the lowest score and 84 is the highest score. 
The average score is 75,07 modus score is 68,00 median score is 75,00 and the standard deviation is 5.19 .

Table 4. Data of Right Brain Dominant Students' Speaking Skill Resulting from Role Play Technique $\left(\mathrm{A}_{1} \mathrm{~B}_{1}\right)$

\begin{tabular}{|c|c|c|}
\hline \multicolumn{3}{|c|}{ Statistics } \\
\hline \multicolumn{3}{|c|}{ A1B1 } \\
\hline $\mathrm{N}$ & Valid & 14 \\
\hline & Missing & 13 \\
\hline & & 75.0714 \\
\hline & & 1.38859 \\
\hline & & 75.0000 \\
\hline Mo & & $68.00^{\mathrm{a}}$ \\
\hline & & 5.19562 \\
\hline & & 26.995 \\
\hline & & 16.00 \\
\hline & & 68.00 \\
\hline & & 84.00 \\
\hline Su & & 1051.00 \\
\hline
\end{tabular}

The position of median score is exactly the same as the average score which is 75 . It is also found that the modus score is exactly the same as the average and the median ones. This score indicates that the number of students who receive higher score than the average one is quite

balance with the number of students who receive score below the average one.

The score of speaking skill of the right brain dominant students who study with role play technique as shown in table 4.5 indicates that 8 students or $57 \%$ have score on the position of under the average range and 6 students or $43 \%$ are above the average range.

\section{Data of Left Brain Dominant Students \\ Speaking Skill Resulting from Role Play Technique $\left(A_{1} B_{2}\right)$}

The speaking skill of the left brain dominant students who study with the role play technique started from 68 as the lowest score to 80 as the highest score. The statistics analysis shows that the average score is 74,10 , and the median score is 74,00 with deviation standard of
4,36 . The multiple modes exist, but the smallest mode score is 68,00 .

Table 5. Data of Left Brain Dominant Students

Speaking Skill Resulting from Role Play Technique $\left(\mathrm{A}_{1} \mathrm{~B}_{2}\right)$

\section{Statistics}

A1B2
\begin{tabular}{|l|r|}
\hline \multicolumn{1}{|c|}{ Valid } & Missing \\
Mean & 10 \\
Std. Error of Mean & 74.1000 \\
Median & 1.37800 \\
Mode & 74.0000 \\
Std. Deviation & $68.00^{\mathrm{a}}$ \\
Variance & 4.35762 \\
Range & 18.989 \\
Minimum & 12.00 \\
Maximum & 68.00 \\
Sum & 80.00 \\
\hline
\end{tabular}

a. Multiple modes exist. The smallest value is showr

The position of median score and mean score are closely attached. Since the score of mean is slightly lower than the average range (mean) it can be indicated that the speaking score of the students who study with information gap is categorized as low. 5 of 10 students or $50 \%$ of the students who are left brain dominant have the speaking score under the average range, 2 or $20 \%$ of the students have the speaking score in the average range and 3 or $30 \%$ of the students have scores above the average range.

\section{Data of Students' Speaking Skill Resulting from Information Gap Technique (A2)}

The whole scores of students' speaking skill assessment resulting from information gap technique range between 60 , the lowest, and 80 , the highest score. By using role play technique students in this study received average score of 68.54 , with modus 
score of 72,00 median score of 69,00 and deviation standard of 5,67.

Table 6. Data of Students' Speaking Skill

$\begin{aligned} & \text { Resulting from Information Gap } \\ & \text { Technique }\end{aligned}$
(A2)

Statistics

\begin{tabular}{|c|c|c|}
\hline \multirow[t]{2}{*}{$\mathrm{N}$} & Valid & 24 \\
\hline & Missing & 3 \\
\hline & & 68.5417 \\
\hline & & 1.15780 \\
\hline & & 69.0000 \\
\hline Mo & & 72.00 \\
\hline & & 5.67205 \\
\hline & & 32.172 \\
\hline & & 20.00 \\
\hline & & 60.00 \\
\hline & & 80.00 \\
\hline Sur & & 1645.00 \\
\hline
\end{tabular}

Median score and the mean (average) score are closely attached, however, the number of students who receive score above average is relatively smaller than the students who receive the score below the average. This description indicates that the average score of the speaking skill of the students who study with the information gap can be considered low. For of 12 students or about $50 \%$ of the students who have studied with information gap technique are categorized as low, 9 students or 37.5 $\%$ of the students are categorized as medium, and 3 students or $12.5 \%$ of the students who have studied with information gap technique are in the high category.

\section{Data of Right Brain Dominant Students' \\ Speaking Skill Resulting from Information Gap Technique (A2B1)}

In this group of data, the highest speaking score of the left brain dominant students who study with information gap technique is 75 and the lowest score is 60. The average score (mean) is 68,15 modus score is 70,00 and median score is 70,00 , with standard deviation of 4,88 .

Table 7. Data of Right Brain Dominant Students'

Speaking Skill Resulting from Information Gap Technique (A2B1)

Statistics

\begin{tabular}{|c|c|c|}
\hline \multicolumn{3}{|c|}{ A2B1 } \\
\hline $\bar{N}$ & Valid & 13 \\
\hline & Missing & 14 \\
\hline \multicolumn{2}{|c|}{ Mean } & 68.1538 \\
\hline \multicolumn{2}{|c|}{ Std. Error of Mean } & 1.35328 \\
\hline \multicolumn{2}{|c|}{ Median } & 70.0000 \\
\hline \multicolumn{2}{|c|}{ Mode } & 70.00 \\
\hline \multicolumn{2}{|c|}{ Std. Deviation } & 4.87931 \\
\hline \multicolumn{2}{|c|}{ Variance } & 23.808 \\
\hline \multicolumn{2}{|c|}{ Range } & 15.00 \\
\hline \multicolumn{2}{|c|}{ Minimum } & 60.00 \\
\hline \multicolumn{2}{|c|}{ Maximum } & 75.00 \\
\hline \multicolumn{2}{|c|}{ Sum } & 886.00 \\
\hline
\end{tabular}

There are 7 students or $53.8 \%$ of the total number of students who are right brain dominant studying with information gap have score under the average range, 3 students or $23.1 \%$ at the average range, and only 3 students or $23.1 \%$ get the score higher than the average range. Since the average score is lower than the median score, it can be said that the whole score of speaking of this group can be considered as low.

The frequency scores of the right brain dominant students who study with information gap technique.

\section{Data of Left Brain Dominant Students' \\ Speaking Skill Resulting from Information Gap Technique (A2B2)}

The speaking scores of the left brain dominant students who study with information gap technique range 
between 60 , the lowest and 80 , the highest. The average score is 69,00 , median is 68,00 and mode score is 62,00 with standard deviation of 6,71 .

Table 8. Data of Left Brain Dominant Students Speaking Skill Resulting from Information Gap Technique (A2B2)

Statistics

\begin{tabular}{|l|r|}
\hline A2B2 & \multicolumn{2}{|c|}{$\begin{array}{c}\text { Valid } \\
\text { Missing }\end{array}$} \\
& 11 \\
Mean & 69.0000 \\
Std. Error of Mean & 2.02260 \\
Median & 68.0000 \\
Mode & $62.00^{\mathrm{a}}$ \\
Std. Deviation & 6.70820 \\
Variance & 45.000 \\
Range & 20.00 \\
Minimum & 60.00 \\
Maximum & 80.00 \\
Sum & 759.00 \\
\hline
\end{tabular}

a. Multiple modes exist. The smallest value is $\mathrm{sh}$

The position of median score is closely attached to the mean score. This position indicates that the number of students who receive score above average is relatively bigger than the students who receive the score below the average. This description indicates that the average score of the speaking skill of the students who study with the information gap can be considered high.

There are two students or $18 \%$ of the total numbers get the score below average range, and about $28 \%$ get speaking score above the average, and the rest of the students about $45 \%$ are in the range of average scores. The distribution of the scores in this group of data can be categorized as high.

The research finding shows that the speaking skill of the students who study with role play technique is significantly different from the speaking skill of the students who sudy with information gap. In other words, the use of role play technique in teaching speaking is more effective than information gap technique. It can be seen from the average score of the students who study with role play technique and the average score of the students who study with information gap technique. The average score of the students who study with role play technique is higher than the average score of the students who study with information gap technique.

The use of role play technique in the learning and teaching process can give beneficial advantages for both the teacher and the students. For the students, role play activity is more interesting and it encourages them to use the language more. Students can experience the target language in context to learn how to interpret and exchange meanings for real life communication.

In role play class, the learning activity can be applied in multiple setting and the students create the interaction and use language freely. They are more motivated to expand and to practice their English. In such circumstances, learning goals make more sense to the students. Therefore, the students usually consider this type of learning as a fun activity. As the result, it can encourage the students to participate in the language learning process actively. Active participation in the use of English during the classes is the corner stone of the successful language learning. The teacher does not need to spend hours to explain about the materials. The teacher only needs to facilitate the students with the communicative atmosphere and stimulate them to be actively involved in the learning.

Since the left brain dominant students tend to rely on thinking and remembering, information gap technique is more advantageous for them. In information gap activity, teacher usually provides students with appropriate forms to be used and the students have to 
complete the information that is not known by them and give the information that is known by them to their partners. Role play technique is more advantageous than information gap technique for both right and left brain dominant students. It can be seen from the average score of the left brain dominant students who study with role play and information gap. Regarding to the fact above, it can be concluded that the teaching techniques and learning styles cannot give effect on the students' speaking skill. As shown in the preceding part, role play technique is more beneficial for the right brain dominant students, and information gap technique is expected to give more advantages to the left brain dominant students. Since there are various kinds of students in the class, teachers are demanded to be able to apply various techniques in the language learning process in order to eliminate the students' failure.

\section{CONCLUSION}

Based on the analysis of the data, the findings of this research are: the speaking skill of the students who study through Role Play technique is higher than the students who study through information gap technique. In other words, role play technique gives more advantages to the students' speaking skill than information gap technique does; the speaking skill of the right-brain dominant students did not affect from role play technique is higher than information gap technique. This means that role play technique is not more effective than information gap technique to increase speaking skill for the right brain dominant students. The speaking skill of left-brain dominant students did not affect from Information gap technique is lower than role play techique. This means that role play technique is not more effective than information gap technique to increase speaking skill for the left brain dominant students. Hence, in the other hand the result is there is not an influence of interaction between teaching techniques and learning styles on the students speaking skill. It can be concluded that teaching techniques and learning styles cannot affect the students' speaking skill.

\section{REFERENCES}

Jefferson, A. (2007). Making Students To Be Brave Speak. New York: Prentice Hall International ELT.

Jordan, R. R. (2009). Teaching Speaking for Beginner. Collins: London and Glasgow.

Jolliffe, W. (2007). Cooperative Learning in the Classroom. London: Paul Chapman Publishing.

Patel, D. M., \& Jain, P. M. (2008). English Language Teaching (Methods, Tools, and Techniques). Vaishali Nagar: Sunrise Publishers \& Distributors.

Philips, J. (2007). Speaking Technique. Boston: Little, Brown and Co.

Zwiers, J. (2010). Building Reading Comprehension Habits. Newark: Congress Catalogue-in-Data Publication.

Kodotchigova, M. A. Role Play in Teaching Culture, Tomsk State University, Russia from taken http://iteslj.org/Techniques/Kod otchigova-rolePlay.html. 